\title{
Comparisons of methods to obtain insoluble particles in snow for transmission electron microscopy
}

Yong Ren ${ }^{\mathrm{a}, \mathrm{b}}$, Xiongfei Zhang ${ }^{\mathrm{b}}$, Hailun $\mathrm{Wei}^{\mathrm{a}}$, Liang $\mathrm{Xu}^{\mathrm{b}}$, Jian Zhang ${ }^{\mathrm{b}}$, Jiaxing Sun ${ }^{\mathrm{b}}$, Xin Wang ${ }^{\text {a,* }}$, Weijun $\mathbf{L i}^{\mathrm{b}, *}$

${ }^{a}$ Key Laboratory for Semi-Arid Climate Change of the Ministry of Education, College of Atmospheric Sciences, Lanzhou University, Lanzhou 730000, Gansu, China

${ }^{\mathrm{b}}$ Environment Research Institute, Shandong University, Jinan Shandong 250100, China

corresponding author: Weijun Li (liweijun@ sdu.edu.cn) and Xin Wang (wxin@lzu.edu.cn) 


\section{ABSTRACT}

Most studies of insoluble particles in snow have been focused on their mass concentration. Little is understood about the physicochemical properties of individual insoluble particles in snow. However, the information is essential to trace sources of the particles, to understand ice nuclei, and to quantify critical aerosol particles (e.g., black carbon) in snow analyzed by bulk methods. The lack of individual particle analyses of snow meltwater stems from the difficulty of producing feasible samples of the snow-borne insoluble particles. In this study, we examined six sample preparation methods and compared their results using transmission electron microscopy (TEM). The results are the following: (1) Drop-by-drop method (DDM) is the easiest method to make TEM samples but cannot remove the influence of the dissolved substances in snow meltwater. (2) Direct filtration method (DFM) was infeasible because the water penetration of carbon film on copper TEM grids is low. (3) Filtration and transfer method (FTM) is through using ultrasonication to transfer insoluble particles on the nuclepore polycarbonate membranes to TEM grids. The drawback of this method is that ultrasonication breaks individual particles into fragments. (4) Freeze-drying method (FDM) can result in new particles from the drying dissolved substances, which interferes with the identification of insoluble particles. (5) Dilution-gravity separation method (DGM) can obtain different substances based on their specific gravity in long standing water. The method can effectively reduce soluble substances but lose insoluble carbonaceous particles (e.g., soot and organic particles). (6) Tangential flow filtration and dilution (TFF-D) through concentrating and desalting dissolved substances is to remove the dissolved substances but keep insoluble particles in snow meltwater. The TFF-D method not only can be suitable for electron microscopy to study individual insoluble particles in snow meltwater but also for any offline microscopic observation such as Raman spectroscopy and mass spectrometry. Keywords: snow, transmission electron microscopy, tangential flow filtration and dilution, ice nuclei 


\section{Introduction}

The prerequisite to form snow is ice nuclei (IN), which are mostly heterogeneous (Szyrmer and Zawadzki, 1997). These heterogeneous processes initially start with some typical aerosol particles (e.g. mineral dust (MD), carbonaceous, and bioorganic particles) that lead to the formation of IN in the atmosphere (Morris et al., 2004; Rogers et al., 2001; Tobo et al., 2013). Therefore, studying particles in the falling snow collected in a remote site can further the understanding of ice nuclei (Creamean et al., 2015; Rangel-Alvarado et al., 2015). Moreover, the fallen snow can trap additional aerosol particles through below-cloud scavenging and dry deposition of aerosol particles (Voisin et al., 2012; Zhang et al., 2013a).

The insoluble impurities in snow on the ground surface also alter the physical and chemical characterization of the snow mantle (Bartels-Rausch et al., 2014; Hadley and Kirchstetter, 2012). Black carbon (BC), a major component of soot particles, has strong light absorption that can decrease the snow albedo (Hadley and Kirchstetter, 2012; Wang et al., 2014). As a result, it affects the melting of snow and changes the radiative climate forcing (Flanner et al., 2007; Huang et al., 2011). However, mineral dust (MD) particles and insoluble organic carbon (OC) can also change snow refraction with their light absorption abilities (Doherty et al., 2010; Painter et al., 2007). Furthermore, the analysis of insoluble impurities or particles in precipitations can also improve the understanding of the aerosol-cloud-precipitation interactions (Creamean et al., 2013), especially the IN particles which are mainly comprised of the insoluble materials (Field et al., 2006). For example, the dust and biological aerosols can transport from Taklimakan and the Gobi desert in Asia to the west coast of the USA, and influence precipitation in the Western regions of America (Ault et al., 2011; Creamean et al., 2015). For all these reasons it is desirable and necessary to study the insoluble impurities in the snow or ice.

Many different analytical methods have been employed to study snow insoluble impurities. For example, the optical absorption and thermo-optical analysis methods are both bulk sample analyses that can provide mass concentrations of insoluble aerosol species, such as BC, MD or insoluble OC in the fallen snow (Doherty et al., 
2014; Wang et al., 2013; Xu et al., 2006; Zhang et al., 2013b). Moreover, single particle analytical methods can accurately identify particle types and provide size and number/mass concentrations of individual particles (Li et al., 2016). For example, the online single particle analysis methods such as single particle soot photometer (SP2) and aerosol time-of-flight mass spectrometry (ATOFMS) have been used to study the size distribution and mass concentrations of $\mathrm{BC}$ in fallen snow and the chemical composition (e.g. dust, biological, biomass burning, and anthropogenic pollutants) of insoluble aerosol residues from snow (Creamean et al., 2015; Schwarz et al., 2012; Schwarz et al., 2013). Their results were important to understand insoluble pollutants in fallen snow or snowfall in different areas; they also have the potential to determine the composition of IN. However, all of these studies have various errors in measuring aerosol species in melted snow waters. For example, the exact temperature to measure elemental carbon (EC) in thermo-optical analysis, the multiple light scattering caused by filters in optical absorption analysis, and the atomizing of liquid samples in SP2 and ATOFMS, introduce multiple and important uncertainties (Doherty et al., 2010; Fung et al., 2002; Lack et al., 2014; Moosmueller et al., 2009; Schwarz et al., 2012). Moreover, the above-mentioned methods provide no information about particle shape, that in part influences the formation potential of particulate IN and their optical properties (Bohren, 1986; Domine et al., 2013; Szyrmer and Zawadzki, 1997).

Electron microscopy, a single-particle analytical method, that can obtain morphology, mixing state, size distributions and elemental composition of individual particles, is a powerful and significant method to examine individual particles in the atmosphere (Li et al., 2016; Posfai and Buseck, 2010). Scanning electron microscopy (SEM) has been used to observe the surface information of insoluble particles in snow (Cong et al., 2009; Creamean et al., 2016; Yu et al., 2015). Although insoluble particles in melting snow can easily be filtered onto nuclepore membrane filters for SEM analysis, SEM is limited to determining aspects of the particle interior and mixing state of ultrafine carbonaceous aerosols (Li et al., 2016). To remedy this deficiency, transmission electron microscopy (TEM) has sufficient resolution to elucidate the structure and composition of snow-borne ultrafine particles (Mortazavi 
et al., 2015; Rangel-Alvarado et al., 2015). However, we found one major problem in these studies, i.e. TEM cannot produce high resolution images of individual snow-borne particles, because it is exceedingly difficult to isolate insoluble particles from melting snow onto TEM grids.

To solve the problem, we designed a series of laboratory experiments to evaluate the feasibility of transfering insoluble particles from melting snow onto TEM grids. In this study, common TEM grids of 300-mesh copper coated with carbon film were used, and we investigated and compared different pretreatment methods though TEM images of the insoluble snow-borne particles.

\section{Snow sample collection and analysis}

The snow samples were collected from 18 January to 14 February, 2015 at Jilin City $\left(43^{\circ} 87^{\prime} \mathrm{N}, 126^{\circ} 57^{\prime} \mathrm{E}\right)$ in northeast China. We used polyethylene containers, which were cleaned with ethanol and ultrapure water, to collect snowfall on the rooftop of a four-story building. Eight snow samples were obtained and each snowfall sampling time almost covered the whole precipitation process. After collection, snow samples were melted rapidly in a glass beaker in a microwave oven. Then this melted snow water was transferred to polyethylene bottles and frozen for future studies. The detailed collection procedure has been described elsewhere (Doherty et al., 2010; Wang et al., 2013). In this study, we roughly observed the meltwater of the eight samples respectively through the TEM by drop-by-drop method (DDM) (Sect. 3. 1). Inferring from the TEM images, only one of the samples was chose to analyze thoroughly with six methods (Sect. 3). The selected sample was sampled from 08:00 (UTC) to 20:40 (UTC) 12 February 2015.

A JEOL JEM-2100 TEM operated at 200kV was employed to study the insoluble particles on TEM grids and an energy-dispersive X-ray spectrometer (EDS) semi-quantitatively determined the elemental composition of the residues. $\mathrm{Cu}$ was excluded from the analyses because TEM grids are made of $\mathrm{Cu}$.

\section{Results and discussion}




\subsection{Drop-by-drop method (DDM)}

Stored in polyethylene bottles in a freezer, the snowfall water was melted at room temperature and then shook to distribute the impurities uniformly throughout the liquid. We used pipettes to transfer one drop onto a TEM grid. The TEM grid was dried in a sealed container containing silica-gel desiccants (Fig. 1). In this experiment, only one drop (about $0.03 \mathrm{~mL}$ ) was transferred onto the TEM grid in each sample.

After the meltwater on a TEM grid evaporated, the solute residues were deposited on the substrate. Fig. $2 \mathrm{~b}$ shows that the residues mostly contain the viscose-like species which occurred throughout the entire drop. EDS shows that viscose-like

species mainly include $\mathrm{Ca}, \mathrm{Cl}$, and $\mathrm{Si}$. Based on the EDS and morphology, we also found some tiny crystaline $\mathrm{NaCl}$ particles, insoluble organics, and fly ash particles (Fig. 2b) (Li et al., 2016). Although we can identify the coarse insoluble particles resulting from the DDM, viscose-like Ca-rich and other soluble residues on the substrate severely influence the TEM image resolution of individual insoluble particles.. Moreover, when we used EDS to determine particle composition, the soluble residues on the substrate interfere with the detection of the chemical composition of the insoluble particles. For example, an organic particle in Fig. $2 b$ contains much higher $\mathrm{Ca}$ and $\mathrm{Cl}$ concentrations that cannot have arisen from organics in the atmosphere. In brief, the DDM very easily transfers snowfall water onto TEM grids (Murr et al., 2004), but the method is not good for TEM analysis whenever the meltwater contains high concentrations of dissolved substances (Nazarenko et al.; Rangel-Alvarado et al., 2015).

\subsection{Direct filtration method (DFM)}

The direct filtration method (DFM) was designed to filter meltwater through a TEM grid. A TEM holder with $2.6 \mathrm{~mm}$ diameter was designed to hold the TEM grid. The water from the funnel penetrates the TEM film and flows into a conical beaker by reducing the pressure with a hand-pump (Fig. 3). The insoluble particles are left on the TEM film. We can adjust the pressure to control the water flow to reduce TEM grid breakage. 
We used the DFM several times to filter the insoluble particles on two kinds of TEM grids: a copper grid covered by formvar-carbon film and a copper grid covered by a lacy carbon film. We found the following problems: (1) The film on TEM grids became fragile during the long duration of the filtering and because of the additional pressure. The TEM film broke under different pressures (Fig. 3). (2) TEM observations show that coarse particles and a few fine particles were left on the TEM grid after the DFM (Fig. 4). These results suggest that the broken film after the DFM influenced the particle distribution on the substrate. The filtration ability of the TEM grids was quite weak for fine insoluble particles, although the DFM can remove the soluble species, as shown in Fig. 4. As a result, we confirm that the DFM is unable to transfer insoluble particles from the meltwater onto TEM grids.

\subsection{Filtration and transfer method (FTM)}

The design of the FTM is same as the DFM except nuclepore polycarbonate membrane replaces the TEM grid in the equipment. Because the nuclepore membrane contains uniform pores with nanometer diameter, it can filter insoluble particles in the meltwater. After filtration the dry nuclepore membrane has been used for scanning electron microscope (SEM) observations (Cong et al., 2009; Ellis et al., 2015). However, unlike SEM, TEM can efficiently observe the ultrafine particles and their particle mixing state. To further observe fine and ultrafine particles, some studies presented methods to transfer the insoluble particles onto TEM grids from the nuclepore membrane (Ellis et al., 2015; Gaudichet et al., 1986). We washed insoluble particles on the nuclepore membrane into ultrapure water and then used DDM to make TEM samples (Fig. 5). It is expected that the FTM can reduce the soluble species impacts on TEM grid, which commonly occurs in DDM as shown in Fig. 2. We carefully conducted the experiments and tested the FTM with TEM.

Fig. 5 shows the filtration system. In this study, nuclepore polycarbonate membranes with $100 \mathrm{~nm}$ pore-size (47 mm diameter, VCTP04700, Merck Millipore) were used to filter the meltwater. The residues on the membrane were then extracted into $5 \mathrm{~mL}$ ultrapure water with a sonic oscillator for 3 minutes. The extracted solution 
was dropped onto TEM grids using the DDM.

We used TEM to examine insoluble particles on the TEM grids and found the following problems: (1) TEM observations show that many particle fragments occur on the substrate (Fig. 6). We speculate that the ultrasonic processes broke individual particles into different fragments. (2) We still found many soluble species on the substrate from the residues on the nuclepore membranes (Fig. 6). Therefore, the FTM fails to filter and transfer insoluble particles from the meltwater onto TEM grids.

\subsection{Freeze-drying method (FDM)}

The FDM was used to remove the moisture of frozen samples through ice sublimation. Physical and chemical damages of different species in the samples were inhibited at low temperature (Kasper and Friess, 2011; Sanchez et al., 2011). Therefore, the FDM has been used to concentrate snow samples, but water in the container was not completely evaporated (Bazzano et al., 2015; Rangel-Alvarado et al., 2015). After the FDM process, these studies further used the DDM to make TEM samples. Although they did obtain insoluble residues from the snowfall samples, the FDM still did not remove disturbances of soluble species. For example, the TEM images showed that insoluble particles on the substrate were influenced by dry, soluble species (Rangel-Alvarado et al., 2015). Evaporating the water completely by FDM had been tried to observe soot particles in ice-cores, but the poor efficiency for ice sublimation of large vacuum and low-particles-concentration Antarctic ice-cores made this test not be achieved at last (Ellis et al., 2015). In this study, we attempted to completely evaporate water in the snowfall samples through the FDM and then to obtain powder samples. Finally, we can move the powder onto the TEM grids.

The FDM consisted of two steps. First, $5 \mathrm{~mL}$ of meltwater was refrozen again in glass beakers covered with pored parafilm (Fig. 7). Then, the ice was sublimed fully in vacuum. The particle powders in the bottom of beakers were moved onto the TEM grids. After freeze-drying, the soluble substances formed fluffy and flocculent particles and these new-formed particle containing abundant $\mathrm{Ca}$ from EDS analysis (Fig. 8b). Insoluble particles could not be clearly identified due to interference by the 
soluble residues. Therefore, we conclude that the FDM was impracticable whenever the content of dissolved substances was high.

\subsection{Dilution-gravity separation method (DGM)}

The dilution-gravity separation method (DGM) was attempted to preprocess samples. The gravity separation was used to obtain different substances based on their specific gravity (Falconer, 2003). Insoluble particles with high specific gravity can be separated from those with low specific gravity. In the DGM, $20 \mathrm{~mL}$ of meltwater was transferred into the clean glass beakers, diluted by $80 \mathrm{~mL}$ ultrapure water, and sealed using the parafilm (Fig. 7). This diluted solution was stored in the dark at $2^{\circ} \mathrm{C}$ for 36 $\mathrm{h}$, then $80 \mathrm{~mL}$ of the solution were removed from the upper layer. The rest solution was further diluted back to $100 \mathrm{~mL}$ and the DDM was used to make TEM samples.

TEM images show that the DGM effectively reduced the influence of soluble substances on the substrate. Fig. 8 shows that fly ash and mineral particles, which are typical insoluble particles in the atmosphere ( $\mathrm{Li}$ et al., 2014), were distinctly identified. As a result, the DGM was suitable for the TEM analysis of insoluble particles in snowfall. The DGM was low in cost and easy to perform (Falconer, 2003). However, we didn't find any soot and insoluble organic particles, which are common insoluble particles in urban snowfall analyzed by the ATOFMS (Creamean et al., 2015). After the DGM experiment, we found that many insoluble carbonaceous particles (e.g., soot and organic particles) stuck on the container's inwall. The reason could be that insoluble carbonaceous particles have low density, high adsorbent, or unstable insoluble substances in water (Kinase et al., 2016; Ogren et al., 1983). As a consequence, the DGM is applicable to study high specific gravity and chemically stable insoluble particles, such as fly ash, mineral and metals (Fig. 9b-d).

\subsection{Tangential flow filtration and Dilution (TFF-D)}

In the life sciences tangential flow filtration (TFF) has found broad applications in concentrating and desalting dissolved substances. This technique recently was also used to concentrate the soot particles in ice core melt water (Ellis et al., 2015). In the 
present study, a TFF system was designed to concentrate the insoluble particles and reduce the effects of dissolved substances (Fig. 10). The TFF system has three components: (1) The tubing and $150 \mathrm{~mL}$ container (PFA, Polyfluoroalkoxy, ultra-low attachment and low resistance for samples); (2) A peristaltic pump equipped with PVC (Polyvinyl chloride) pump tubing; and (3) a Hollow Fiber Filer (HFF) cartridge. The hollow fibers within the HFF cartridge, is PES (Polyethersulfone) filer membrane $(50 \mathrm{kD}$ of the molecular weight cutoff, about $10 \mathrm{~nm}$ pore size). While the meltwater in a container could be transferred by a peristaltic pump into and through the hollow fibers, the dissolved substances were removed through pores and insoluble particles were pushed forward in the hollow fibers. Because there was flowing water and enough small pore size in the HFF, insoluble particles in water were rarely absorbed onto the inwall of the membrane. As a result, the insoluble particles in meltwater can be concentrated and the concentration of dissolved substances remains constant during the TFF process.

In this study, $100 \mathrm{~mL}$ of meltwater was transferred into the PFA container, pumped through the HFF, and then transported back to the PFA container with a high concentration of insoluble particles (Fig. 10). With a $5 \mathrm{~cm}^{2}$ membrane surface area, $100 \mathrm{~mL}$ melt water was concentrated to $20 \mathrm{~mL}$ in $\sim 6 \mathrm{~h}$. After the FEE, the meltwater sample was dropped onto the TEM grids following diluting back to $100 \mathrm{~mL}$ with the ultrapure water.

The TFF-D system was verified using $200 \mathrm{~nm}$ polystyrene latex (PSL) spheres in $100 \mathrm{ml}$ ultrapure water. The TEM images show that the PSL spheres were well concentrated in the water and were not damaged during the TFF process (Fig. 11). We didn't find any PSL sphere in the filtrated water. This result indicates that the PSL spheres could not penetrate the HFF pores.

Therefore, the TFF-D was an effective method to remove the dissolved substances (Fig. 12a). The insoluble particles, such as fly ash, organics, mineral dust, soot, and biological particles, which are the typical particles in the atmosphere, can be identified (Brown et al., 2011; Li et al., 2016; Seinfeld et al., 2006). The soot particle with special chain-like aggregation morphology (Fig. 12b) was mainly formed from 
fossil fuels and biomass burning (Buseck et al., 2014; Moffet and Prather, 2009). The spheres, shown in Fig. 12c, emitted during the anthropogenic combustion, and composed of $\mathrm{Si}, \mathrm{Al}$ and Fe were named fly ash in TEM studies ( $\mathrm{Li}$ and Shao, 2009; Shi et al., 2003). The irregular mineral and OC particles can be determined by EDS (Fig. 12c-d). The major elements are $\mathrm{Si}$ and $\mathrm{Al}$ for mineral particles and $\mathrm{C}$ for $\mathrm{OC}$ particles (Li et al., 2016). Biological particles also been found (Fig. 12f), and those particles were identified by the special morphologies and the "biogenic elemental fingerprint" (e.g., P, S, Si and Cl with C and O) (Li and Shao, 2009; Moffet et al., 2010). Mineral, fly ash and biological particles can serve as IN and have already been directly observed during the airborne experiments (Creamean et al., 2013). Soot, mineral and OC particles would greatly alter the radiative effects on the snowpack, and these changes are significant for the climate (Doherty et al., 2014; Hadley and Kirchstetter, 2012).

\section{Conclusions}

The summary of different methods for meltwater preprocessing was shown in Table 1. (1) DFM and FTM are infeasible. Traditional carbon film of copper TEM grids has low water penetration ability. Ultrasonication can break insoluble particles into several fragments; (2) FDM is a sensible method to concentrate water samples through ice sublimation in low-temperature conditions. However, dissolved substances can precipitate and influence TEM observations of morphology and composition of insoluble particles; (3) DDM can easily transfer the insoluble particles in meltwater onto TEM grids, but the dissolved substances influence TEM observations of morphology and composition of insoluble particles; (4) DGM and TFF-D can efficiently reduce the influence of dissolved substances by diluting the solution. TFF-D can collect all kinds of typical dissolved particles in atmosphere, while DGM cannot obtain insoluble carbonate particles (i.e. soot and organic particle).

Based on our study, we can recommend an ensemble of methods for further users. First, DDM can be used to evaluate insoluble particles on TEM grids from the 
meltwater. If the concentrations of dissolve substances are low, we can use DDM or FDM to make TEM samples. Second, if the water sample contains abundant soluble substances, we must use TFF-D to dilute the water sample and to make TEM samples. This ensemble of methods is not only suitable for electron microscopy to study individual particles, but also for any offline microscopic techniques such as Raman spectroscopy and mass spectrometry.

\section{Acknowledgments}

We appreciate Peter Hyde's comments and proofreading. This work was funded by the Foundation for Innovative Research Groups of the National Science Foundation of China (41521004), National Natural Science Foundation of China (41575116, and 41522505), and Shandong Provincial Science Fund for Distinguished Young Scholars, China (JQ201413). 


\section{References}

Ault, A.P., Williams, C.R., White, A.B., Neiman, P.J., Creamean, J.M., Gaston, C.J., Ralph, F.M., Prather, K.A., 2011. Detection of Asian dust in California orographic precipitation. Journal of Geophysical Research 116.

Bartels-Rausch, T., Jacobi, H.W., Kahan, T.F., Thomas, J.L., Thomson, E.S., Abbatt, J.P.D., Ammann, M., Blackford, J.R., Bluhm, H., Boxe, C., Domine, F., Frey, M.M., Gladich, I., Guzman, M.I., Heger, D., Huthwelker, T., Klan, P., Kuhs, W.F., Kuo, M.H., Maus, S., Moussa, S.G., McNeill, V.F., Newberg, J.T., Pettersson, J.B.C., Roeselova, M., Sodeau, J.R., 2014. A review of air-ice chemical and physical interactions (AICl): liquids, quasi-liquids, and solids in snow. Atmos. Chem. Phys. 14, 1587-1633.

Bazzano, A., Latruwe, K., Grotti, M., Vanhaecke, F., 2015. Lead isotopic analysis of Antarctic snow using multi-collector ICP-mass spectrometry. J. Anal. At. Spectrom. 30, 1322-1328.

Bohren, C.F., 1986. Applicability of effective-medium theories to problems of scattering and absorption by nonhomogeneous atmospheric particles. J. Atmos. Sci. 43, 468-475.

Brown, P., Jones, T., BeruBe, K., 2011. The internal microstructure and fibrous mineralogy of fly ash from coal-burning power stations. Environ. Pollut. 159, 3324-3333.

Buseck, P.R., Adachi, K., Andras, G., Tompa, E., Mihaly, P., 2014. Ns-Soot: A Material-Based Term for Strongly Light-Absorbing Carbonaceous Particles. Aerosol Sci. Technol. 48, 777-788.

Cong, Z., Kang, S., Qin, D., 2009. Seasonal features of aerosol particles recorded in snow from Mt. Qomolangma (Everest) and their environmental implications. J. Environ. Sci. 21, 914-919.

Creamean, J.M., Ault, A.P., White, A.B., Neiman, P.J., Ralph, F.M., Minnis, P., Prather, K.A., 2015. Impact of interannual variations in sources of insoluble aerosol species on orographic precipitation over California's central Sierra Nevada. Atmos. Chem. Phys. 15, 6535-6548.

Creamean, J.M., Axson, J.L., Bondy, A.L., Craig, R.L., May, N.W., Shen, H., Weber, M.H., Pratt, K.A., Ault, A.P., 2016. Changes in Precipitating Snow Chemistry with Location and Elevation in the California Sierra Nevada. Journal of Geophysical Research Atmospheres.

Creamean, J.M., Suski, K.J., Rosenfeld, D., Cazorla, A., DeMott, P.J., Sullivan, R.C., White, A.B., Ralph, F.M., Minnis, P., Comstock, J.M., Tomlinson, J.M., Prather, K.A., 2013. Dust and Biological Aerosols from the Sahara and Asia Influence Precipitation in the Western U.S. Science 339, 1572-1578.

Doherty, S.J., Dang, C., Hegg, D.A., Zhang, R., Warren, S.G., 2014. Black carbon and other light-absorbing particles in snow of central North America. J. Geophys. Res. Atmos. 119, 12807-12831.

Doherty, S.J., Warren, S.G., Grenfell, T.C., Clarke, A.D., Brandt, R.E., 2010. Light-absorbing impurities in Arctic snow. Atmos. Chem. Phys. 10, 11647-11680.

Domine, F., Bock, J., Voisin, D., Donaldson, D.J., 2013. Can We Model Snow Photochemistry? Problems with the Current Approaches. J. Phys. Chem. A 117, 4733-4749.

Ellis, A., Edwards, R., Saunders, M., Chakrabarty, R.K., Subramanian, R., van Riessen, A., Smith, A.M., Lambrinidis, D., Nunes, L.J., Vallelonga, P., Goodwin, I.D., Moy, A.D., Curran, M.A.J., van Ommen, T.D., 2015. Characterizing black carbon in rain and ice cores using coupled tangential flow filtration and transmission electron microscopy. Atmos. Meas. Tech. 8, 3959-3969.

Falconer, A., 2003. Gravity Separation: Old Technique/New Methods. Phys. Separ. Sci. Eng. 12, 31-48.

Field, P.R., M?hler, O., Connolly, P., Kr?mer, M., 2006. Some ice nucleation characteristics of Asian and Saharan desert dust. Atmospheric Chemistry \& Physics 6, 2991-3006. 
Flanner, M.G., Zender, C.S., Randerson, J.T., Rasch, P.J., 2007. Present-day climate forcing and response from black carbon in snow. J. Geophys. Res. Atmos. 112.

Fung, K., Chow, J.C., Watson, J.G., 2002. Evaluation of OC/EC speciation by thermal manganese dioxide oxidation and the IMPROVE method. J. Air Waste Manage. Assoc. 52, 1333-1341.

Gaudichet, A., Petit, J.R., Lefevre, R., Lorius, C., 1986. An investigation by analytical transmission electron microscopy of individual insoluble microparticles from Antarctic (Dome C) ice core samples. Tellus Ser. B-Chem. Phys. Meteorol. 38B, 250-261.

Hadley, O.L., Kirchstetter, T.W., 2012. Black-carbon reduction of snow albedo. Nat. Clim. Chang. 2, 437-440.

Huang, J., Fu, Q., Zhang, W., Wang, X., Zhang, R., Ye, H., Warren, S.G., 2011. DUST AND BLACK CARBON IN SEASONAL SNOW ACROSS NORTHERN CHINA. Bull. Amer. Meteorol. Soc. 92, 175-+.

Kasper, J.C., Friess, W., 2011. The freezing step in lyophilization: Physico-chemical fundamentals, freezing methods and consequences on process performance and quality attributes of biopharmaceuticals. Eur. J. Pharm. Biopharm. 78, 248-263.

Kinase, T., Kita, K., Tsukagawaogawa, Y., Gotoazuma, K., Kawashima, H., 2016. Influence of the melting temperature on the measurement of the mass concentration and size distribution of black carbon in snow. Atmos. Meas. Tech. 9, 1939-1945.

Lack, D.A., Moosmueller, H., McMeeking, G.R., Chakrabarty, R.K., Baumgardner, D., 2014. Characterizing elemental, equivalent black, and refractory black carbon aerosol particles: a review of techniques, their limitations and uncertainties. Anal. Bioanal. Chem. 406, 99-122.

Li, W., Shao, L., 2009. Transmission electron microscopy study of aerosol particles from the brown hazes in northern China. J. Geophys. Res. Atmos. 114.

Li, W., Shao, L., Shi, Z., Chen, J., Yang, L., Yuan, Q., Yan, C., Zhang, X., Wang, Y., Sun, J., Zhang, Y., Shen, X., Wang, Z., Wang, W., 2014. Mixing state and hygroscopicity of dust and haze particles before leaving Asian continent. J. Geophys. Res. Atmos. 119, 1044-1059.

Li, W., Shao, L., Zhang, D., Ro, C.-U., Hu, M., Bi, X., Geng, H., Matsuki, A., Niu, H., Chen, J., 2016. A review of single aerosol particle studies in the atmosphere of East Asia: morphology, mixing state, source, and heterogeneous reactions. J. Clean Prod. 112, 1330-1349.

Moffet, R.C., Henn, T.R., Tivanski, A.V., Hopkins, R.J., Desyaterik, Y., Kilcoyne, A.L.D., Tyliszczak, T., Fast, J., Barnard, J., Shutthanandan, V., Cliff, S.S., Perry, K.D., Laskin, A., Gilles, M.K., 2010. Microscopic characterization of carbonaceous aerosol particle aging in the outflow from Mexico City. Atmos. Chem. Phys. 10, 961-976.

Moffet, R.C., Prather, K.A., 2009. In-situ measurements of the mixing state and optical properties of soot with implications for radiative forcing estimates. Proc. Natl. Acad. Sci. 106, 11872-11877.

Moosmueller, H., Chakrabarty, R.K., Arnott, W.P., 2009. Aerosol light absorption and its measurement: A review. J. Quant. Spectrosc. Radiat. Transf. 110, 844-878.

Morris, C.E., Georgakopoulos, D.G., Sands, D.C., 2004. Ice nucleation active bacteria and their potential role in precipitation. J. Phys. IV 121, 87-103.

Mortazavi, R., Attiya, S., Ariya, P.A., 2015. Arctic microbial and next-generation sequencing approach for bacteria in snow and frost flowers: selected identification, abundance and freezing nucleation. Atmos. Chem. Phys. 15, 6183-6204.

Murr, L.E., Esquivel, E.V., Bang, J.J., de la Rosa, G., Gardea-Torresdey, J.L., 2004. Chemistry and nanoparticulate compositions of a 10,000 year-old ice core melt water. Water Res. 38, 4282-4296. 
Nazarenko, Y., Rangel-Alvarado, R.B., Kos, G., Kurien, U., Ariya, P.A., Novel aerosol analysis approach for characterization of nanoparticulate matter in snow. Environmental Science and Pollution Research, 1-14.

Ogren, J.A., Charlson, R.J., Groblicki, P.J., 1983. Determination of elemental carbon in rainwater. Analytical Chemistry 55, 1569-1572.

Painter, T.H., Barrett, A.P., Landry, C.C., Neff, J.C., Cassidy, M.P., Lawrence, C.R., McBride, K.E., Farmer, G.L., 2007. Impact of disturbed desert soils on duration of mountain snow cover. Geophys. Res. Lett. 34.

Posfai, M., Buseck, P.R., 2010. Nature and Climate Effects of Individual Tropospheric Aerosol Particles, in: Jeanloz, R., Freeman, K.H. (Eds.), Annual Review of Earth and Planetary Sciences, Vol 38, pp. 17-43.

Rangel-Alvarado, R.B., Nazarenko, Y., Ariya, P.A., 2015. Snow-borne nanosized particles: Abundance, distribution, composition, and significance in ice nucleation processes. J. Geophys. Res. Atmos. 120.

Rogers, D.C., DeMott, P.J., Kreidenweis, S.M., 2001. Airborne measurements of tropospheric ice-nucleating aerosol particles in the Arctic spring. J. Geophys. Res. Atmos. 106, 15053-15063.

Sanchez, J., Hernandez, E., Auleda, J.M., Raventos, M., 2011. Review: Freeze Concentration Technology Applied to Dairy Products. Food Sci. Technol. Int. 17, 5-13.

Schwarz, J.P., Doherty, S.J., Li, F., Ruggiero, S.T., Tanner, C.E., Perring, A.E., Gao, R.S., Fahey, D.W., 2012. Assessing Single Particle Soot Photometer and Integrating Sphere/Integrating Sandwich Spectrophotometer measurement techniques for quantifying black carbon concentration in snow. Atmos. Meas. Tech. 5, 2581-2592.

Schwarz, J.P., Gao, R.S., Perring, A.E., Spackman, J.R., Fahey, D.W., 2013. Black carbon aerosol size in snow. Sci Rep 3.

Seinfeld, J.H., Pandis, S.N., Seinfeld, J.H., Pandis, S.N., 2006. Atmospheric chemistry and physics: from air pollution to climate change. Phys. Today 51, 212-214(213).

Shi, Z.B., Shao, L.Y., Jones, T.P., Whittaker, A.G., Lu, S.L., Berube, K.A., He, T., Richards, R.J., 2003. Characterization of airborne individual particles collected in an urban area, a satellite city and a clean air area in Beijing, 2001. Atmos. Environ. 37, 4097-4108.

Szyrmer, W., Zawadzki, I., 1997. Biogenic and anthropogenic sources of ice-forming nuclei: a review. Bull. Amer. Meteorol. Soc. 78, 209-228.

Tobo, Y., Prenni, A.J., DeMott, P.J., Huffman, J.A., McCluskey, C.S., Tian, G., Poehlker, C., Poeschl, U., Kreidenweis, S.M., 2013. Biological aerosol particles as a key determinant of ice nuclei populations in a forest ecosystem. J. Geophys. Res. Atmos. 118, 10100-10110.

Voisin, D., Jaffrezo, J.-L., Houdier, S., Barret, M., Cozic, J., King, M.D., France, J.L., Reay, H.J., Grannas, A., Kos, G., Ariya, P.A., Beine, H.J., Domine, F., 2012. Carbonaceous species and humic like substances (HULIS) in Arctic snowpack during OASIS field campaign in Barrow. J. Geophys. Res. Atmos. 117.

Wang, X., Doherty, S.J., Huang, J., 2013. Black carbon and other light-absorbing impurities in snow across Northern China. J. Geophys. Res. Atmos. 118, 1471-1492.

Wang, X., Xu, B., Ming, J., 2014. An Overview of the Studies on Black Carbon and Mineral Dust Deposition in Snow and Ice Cores in East Asia. J. Meteorol. Res. 28, 354-370. 
Xu, B., Yao, T., Liu, X., Wang, N., 2006. Elemental and organic carbon measurements with a two-step heating-gas chromatography system in snow samples from the Tibetan Plateau, in: MosleyThompson, E., Thompson, L.G. (Eds.), Annals of Glaciology, Vol 43, 2006, pp. 257-262.

Yu, Z.-I., Yang, P.-h., Jing, W.-I., Yuan, D.-X., Ren, K., Li, L.-I., 2015. Characteristics and Resources of Fly Ash Particles in the Snowpack of Jinfo Mountain, Chongqing. Huanjing Kexue 36, 4381-4388.

Zhang, L., Wang, X., Moran, M.D., Feng, J., 2013a. Review and uncertainty assessment of size-resolved scavenging coefficient formulations for below-cloud snow scavenging of atmospheric aerosols. Atmos. Chem. Phys. 13, 10005-10025.

Zhang, R., Hegg, D.A., Huang, J., Fu, Q., 2013b. Source attribution of insoluble light-absorbing particles in seasonal snow across northern China. Atmos. Chem. Phys. 13, 6091-6099. 


\section{Figure captions}

Fig. 1. The schematic process of the drop-by-drop method.

Fig. 2. TEM images and EDS spectra of dry residues from the DDM. (a) low magnification image showing the distribution of dry residues on the substrate. (b) high-magnification image of the soluble and insoluble residues.

Fig. 3. Schematic of direct filtration method.

Fig. 4. TEM images after the DFM. (a) Particle distribution at low magnification (b) Few fine particles on TEM film.

Fig. 5. Schematic of filtration and transfer method (FTM).

Fig. 6. TEM images after the FTM. (a) Substance distribution at low magnification (b) A mineral particle fragment on TEM film.

Fig. 7. Schematics of Dilution-gravity separation method (DGM) and Freeze-drying method (FDM).

Fig. 8. TEM images after the FDM. (a) Residue distribution at low magnification (b) A fluffy and flocculent particle and the EDS spectra of the marked part.

Fig. 9. TEM images of insoluble particles after the DGM process. (a) Residue distribution at low magnification (b) Fly ash. (c) Metal particle. (d) Mineral particle. Fig. 10. Schematic of Tangential flow filtration and Dilution (TFF-D).

Fig. 11. $200 \mathrm{~nm}$ polystyrene latex (PSL) spheres images of TEM after the DFM.

Fig. 12. TEM images after TFF-D. (a) Residue distribution at low magnification (b) Soot. (c) Fly ash. (d) Organic particle. (e) Mineral particle. (f) Biological particle. 

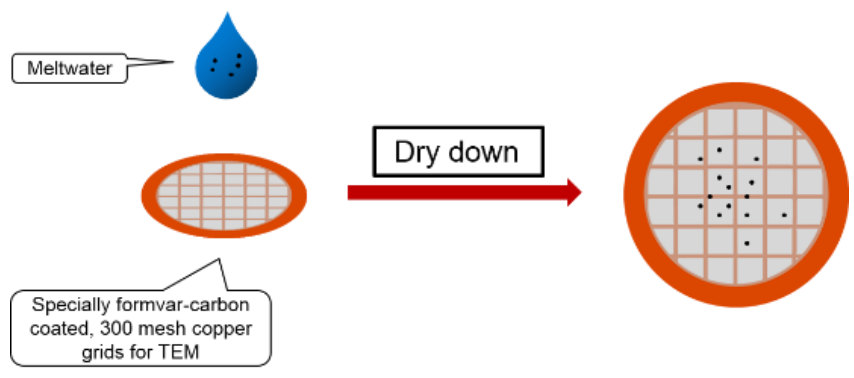

Fig. 1. The schematic process of the drop-by-drop method.
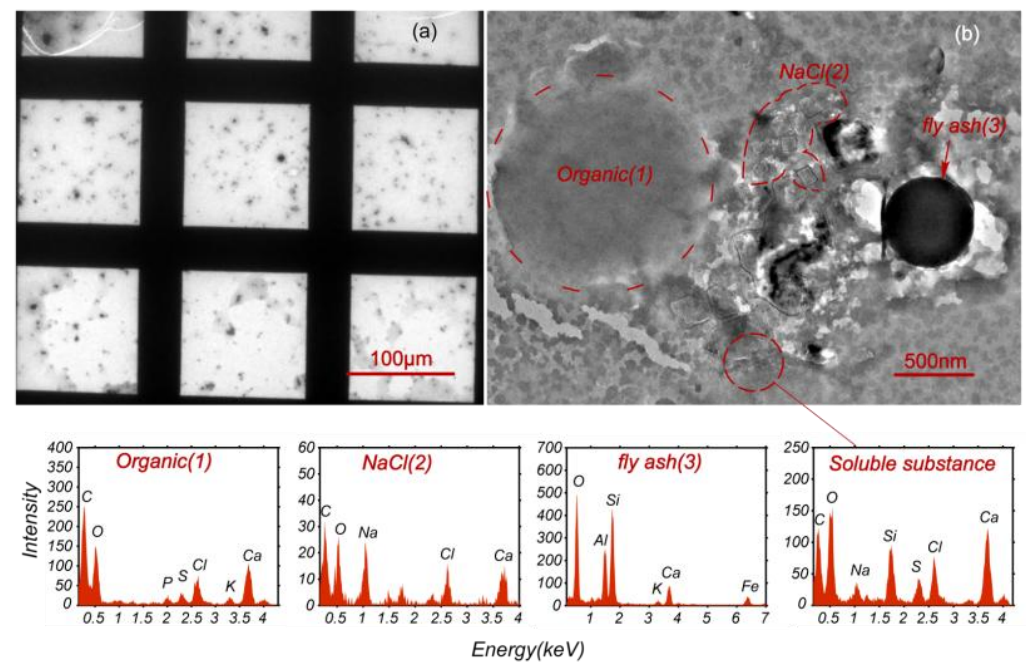

Fig. 2. TEM images and EDS spectra of dry residues from the DDM. (a) low magnification image showing the distribution of dry residues on the substrate. (b) high-magnification image of the soluble and insoluble residues.

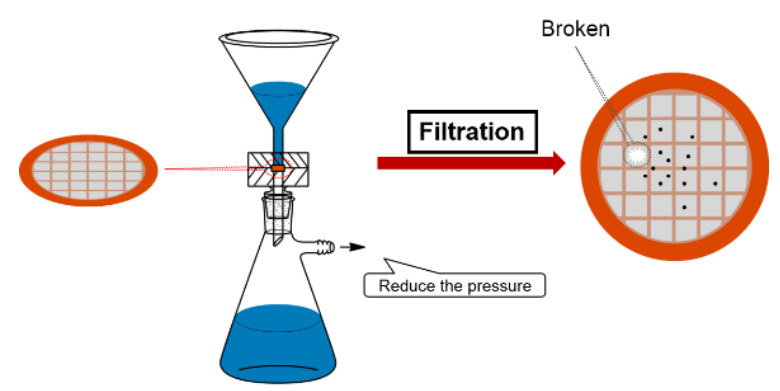

Fig. 3. Schematic of direct filtration method. 


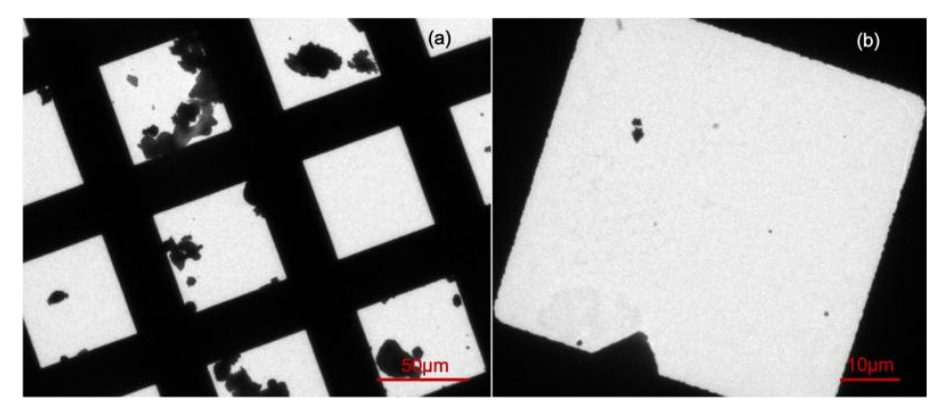

Fig. 4. TEM images after the DFM. (a) Particle distribution at low magnification (b) Few fine particles on TEM film.

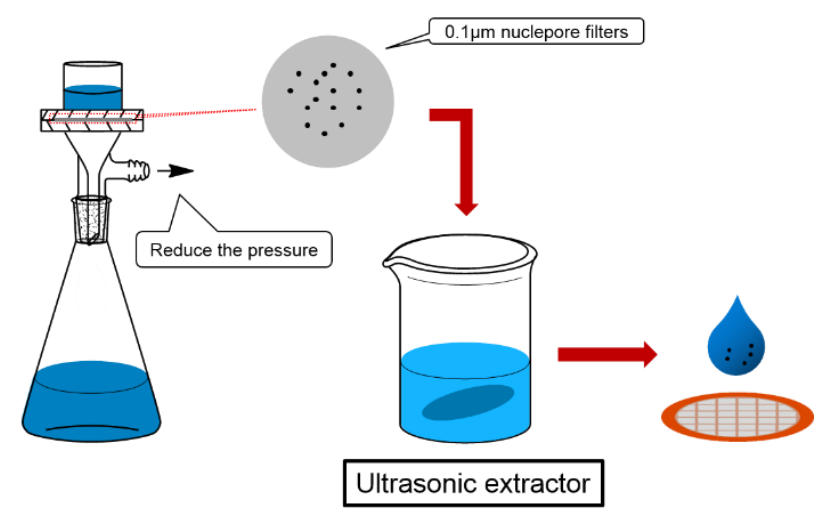

Fig. 5. Schematic of filtration and transfer method (FTM).

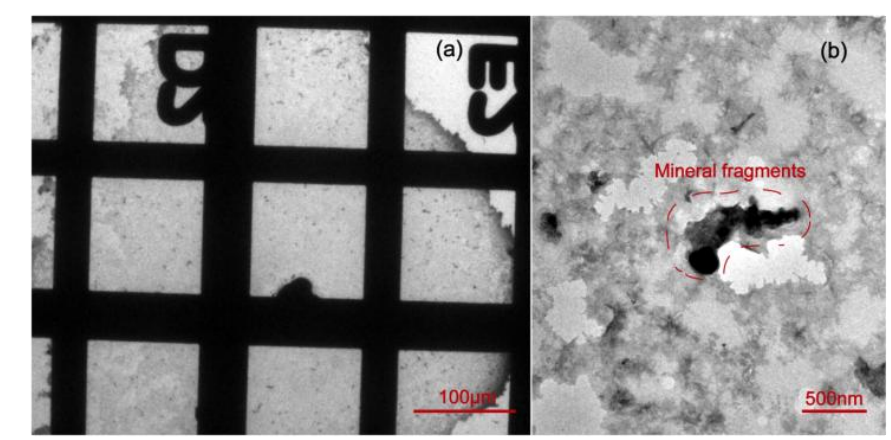

Fig. 6. TEM images after the FTM. (a) Substance distribution at low magnification (b) A mineral particle fragment on TEM film. 

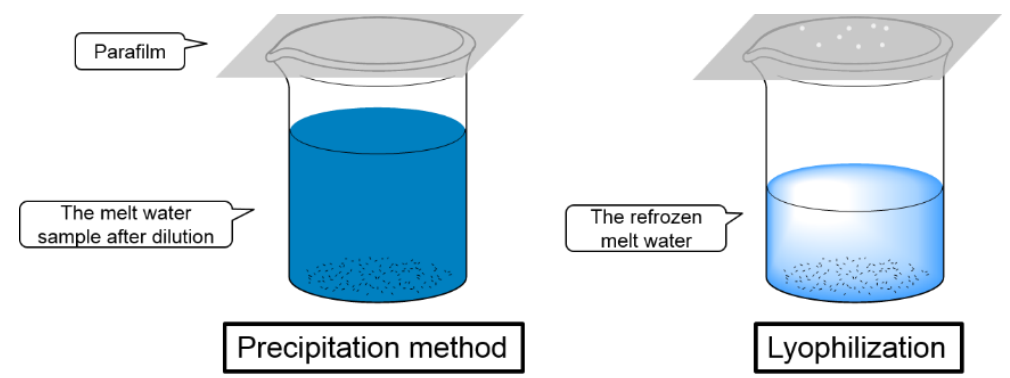

Fig. 7. Schematics of Dilution-gravity separation method (DGM) and Freeze-drying method (FDM).
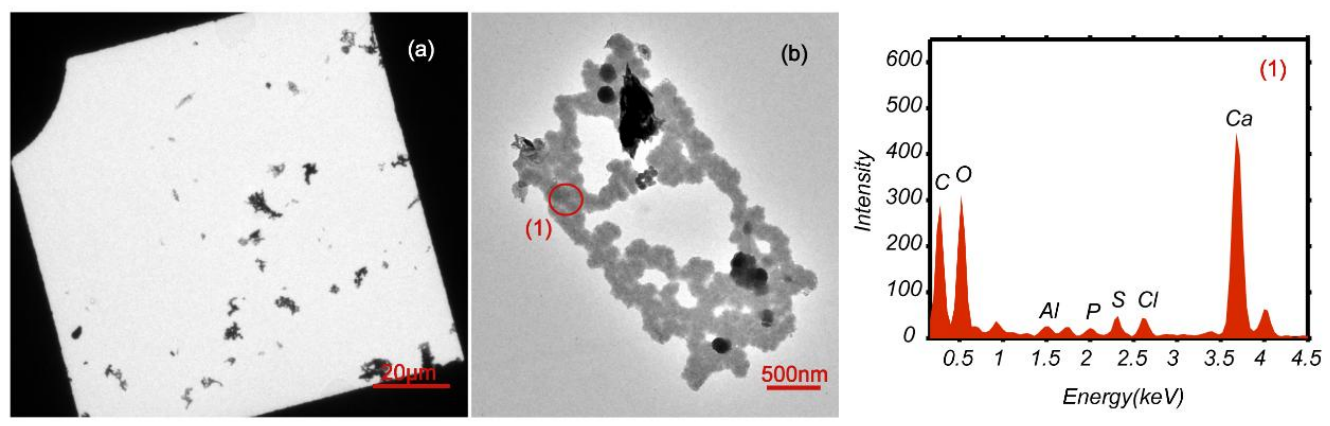

Fig. 8. TEM images after the FDM. (a) Residue distribution at low magnification (b) A fluffy and flocculent particle and the EDS spectra of the marked part.

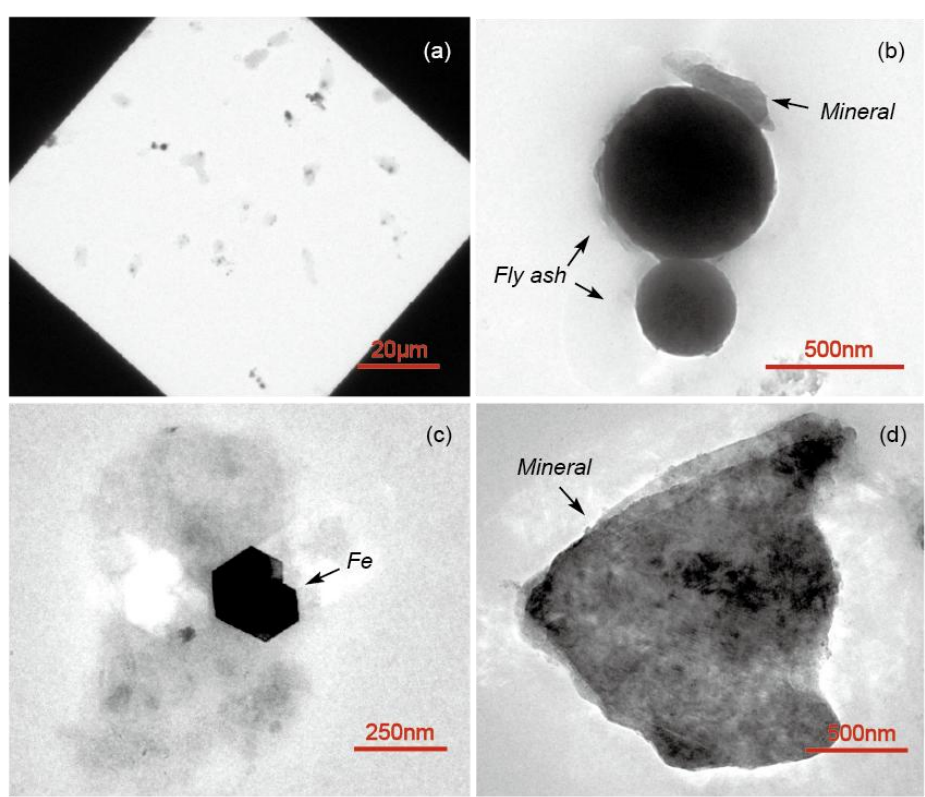

Fig. 9. TEM images of insoluble particles after the DGM process. (a) Residue distribution at low magnification (b) Fly ash. (c) Metal particle. (d) Mineral particle. 


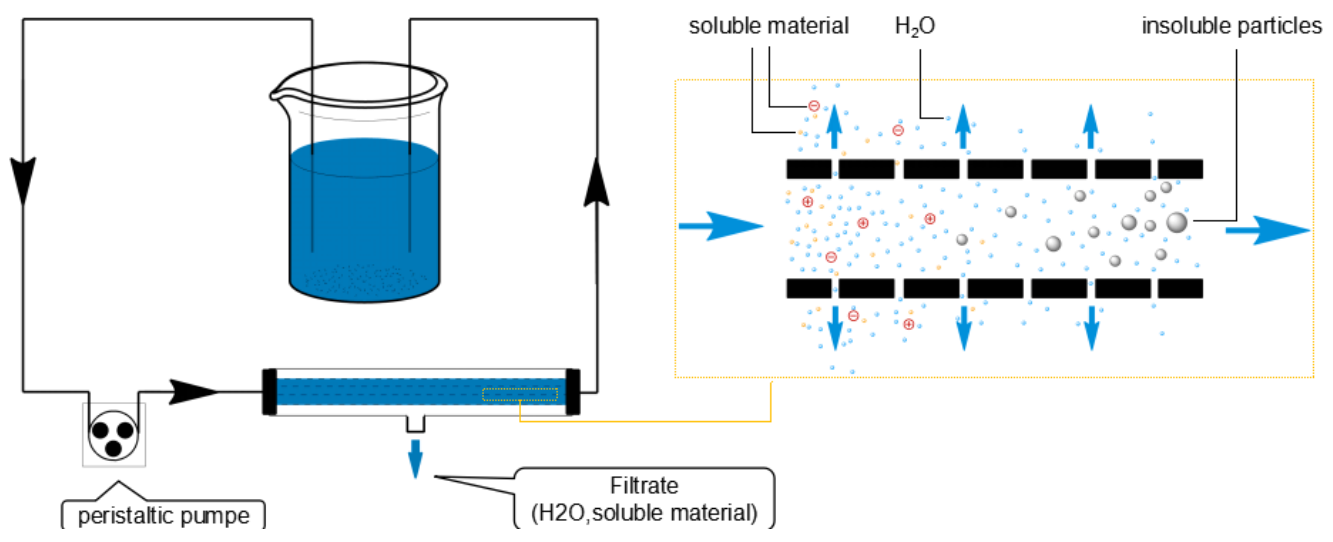

Fig. 10. Schematic of Tangential flow filtration and Dilution (TFF-D).
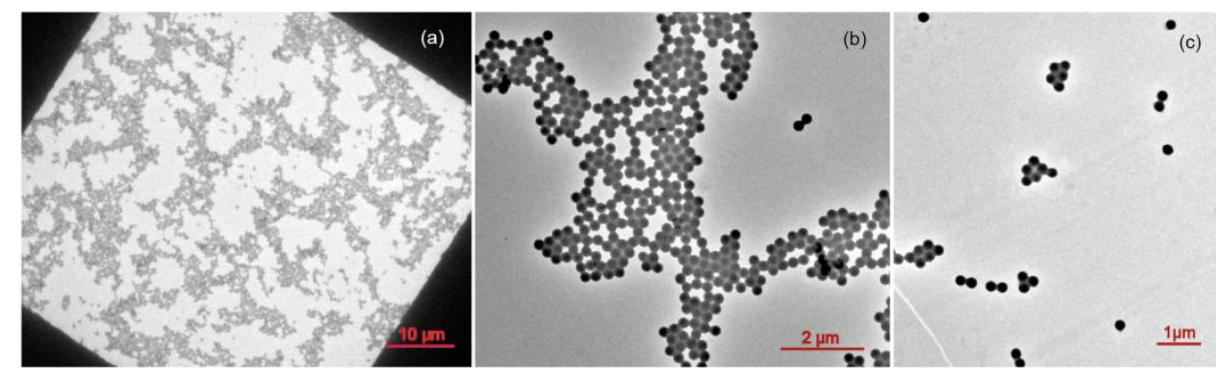

Fig. 11. $200 \mathrm{~nm}$ polystyrene latex (PSL) spheres images of TEM after the DFM.

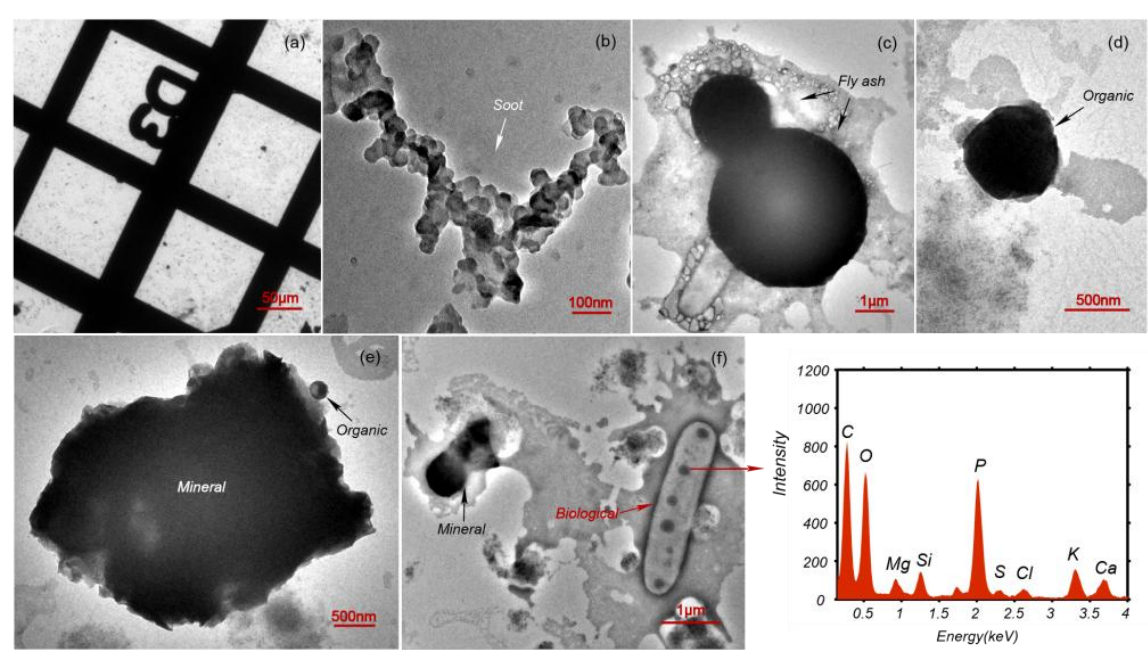

Fig. 12. TEM images after TFF-D. (a) Residue distribution at low magnification (b) Soot. (c) Fly ash. (d) Organic particle. (e) Mineral particle. (f) Biological particle. 


\section{Table}

\section{Table 1}

Summary of different pre-processing methods.

\begin{tabular}{|c|c|c|c|}
\hline Method & Rank & Advantages & Drawbacks \\
\hline $\begin{array}{l}\text { Drop-by-drop } \\
\text { method (DDM) }\end{array}$ & low & Low cost & $\begin{array}{l}\text { Dissolved substances } \\
\text { residues affects the } \\
\text { morphology of insoluble } \\
\text { particles }\end{array}$ \\
\hline $\begin{array}{l}\text { Direct filtration } \\
\text { method (DFM) }\end{array}$ & Fail & - & - \\
\hline $\begin{array}{l}\text { Filtration and } \\
\text { transfer method } \\
\text { (FTM) }\end{array}$ & Fail & - & - \\
\hline $\begin{array}{l}\text { Freeze-drying } \\
\text { method (FDM) }\end{array}$ & Low & $\begin{array}{l}\text { Removal of whole water } \\
\text { of snow; some insoluble } \\
\text { particles can be obtained }\end{array}$ & $\begin{array}{l}\text { Disturbances of the } \\
\text { dissolved substances } \\
\text { cannot be avoid }\end{array}$ \\
\hline $\begin{array}{l}\text { Dilution-gravity } \\
\text { separation } \\
\text { method (DGM) }\end{array}$ & medium & $\begin{array}{l}\text { Low cost; reduce the } \\
\text { impact of dissolved } \\
\text { substances effectively }\end{array}$ & $\begin{array}{l}\text { Loss of carbonaceous } \\
\text { aerosol }\end{array}$ \\
\hline $\begin{array}{l}\text { Tangential flow } \\
\text { filtration and } \\
\text { Dilution } \\
\text { (TFF-D) }\end{array}$ & good & $\begin{array}{l}\text { Excellent concentration of } \\
\text { insoluble particles; } \\
\text { reduced the impact of } \\
\text { dissolved substances } \\
\text { effectively }\end{array}$ & $\begin{array}{l}\text { A clean room laboratory } \\
\text { environment is required }\end{array}$ \\
\hline
\end{tabular}

